\title{
EFFECT OF BREED ON FREQUENCY OF MORPHOLOGICAL DEFECTS IN BOAR SPERMATOZOA
}

\author{
Vendula Kamanová ${ }^{1}$, Pavel Nevrkla ${ }^{1}$,Zdeněk Hadaš ${ }^{1}$ \\ ${ }^{1}$ Department of Animal Breeding, Faculty of AgriSciences, Mendel University in Brno, Zemědělská 1, 61300 Brno, \\ Czech Republic
}

\begin{abstract}
KAMANOVÁ VENDULA, NEVRKLA PAVEL, HADAŠ ZDENĚK. 2018. Effect of Breed on Frequency of Morphological Defects in Boar Spermatozoa. Acta Universitatis Agriculturae et Silviculturae Mendelianae Brunensis, 66(3): 665-668.

The aim of this study was to assess an effect of breed on frequency of morphological changes in boar spermatozoa. A total of 1080 semen samples were used in this study. The samples were collected from January to December 2017 from 90 boars of the Duroc, Czech Large White and Czech Landrace breeds. Sperm cell abnormalities were evaluated microscopically from dyed smears of native semen on glass slides. Defects of spermatozoa were divided according to their impact on fertility of boars into categories of "major defects" (with a great negative effect on fertility) and "minor defects" (with a mild effect on fertility). The overall frequency of spermatozoa with morphological defects ranged from $11.62 \%$ in Czech Landrace to $20.96 \%$ in Duroc. Statistically significant differences were found in the frequencies of both major and minor defects among the breeds. The results of this study document that there are great inter-breed differences in the occurrence of morphologically defective spermatozoa that significantly affect fertility of boars.
\end{abstract}

Keywords: boar, breed, ejaculate, spermatozoa, morphological defect

\section{INTRODUCTION}

Quality of breeding boar is not only reflected in its breeding value, but also in quality of its reproductive functions that delimit exploitation even of excellent breeding boars. Gene pool of the top breeding boars is of a great interest and thus efforts are made to exploit these breeding boars maximally. On the other hand, the quality of semen is highly variable in these boars, which makes production of insemination doses more difficult. In testicles of boars, 15 billions of sperm cells are produced daily (Jelínek and Koudela, 2003). Not all of the produced sperm cells can be characterized as normally developed. In this respect, it can be stated that high sperm production is accompanied by natural production of cells of insufficient quality (Věžník et al., 2004). Morphologically abnormal spermatozoa may decrease fertilization rate and embryo development (Thundathil et al., 2001). Morphological analysis of semen enables description of spermatogenesis and provides information on proportion of spermatozoa without fertilizing capacity. Abnormalities of sperm morphology are classified according to localization of defect (head, midpiece, tail), the place where the defect originated (primary: testes, secondary: epididymis, tertiary: accessory glands/after ejaculation) (Gamčík et al., 1992; Věžník et al., 2004) or their impact on male fertility ("major defects" and "minor defects") (Blom, 1972). Fertilizing capacity of spermatozoa and related fertility of boars depend mainly on the proportion of sperm cells with primary alterations or with "major defects" (Colenbrander and Kemp, 1990; Klupczynski et al., 2000).

The aim of this study was to determine proportion of spermatozoa with morphological alterations in semen samples obtained from boars of various breeds. 


\section{MATERIALS AND METHODS}

The experimental population consisted of Duroc, Czech Large White and Czech Landrace boars from an insemination station in the Czech Republic, which were subjected to the analysis of sperm morphological alterations between January and December 2017. The morphological analysis was performed in 90 boars, 30 individuals from each breed. The mean age of boars was $20 \pm 2$ months at the beginning of observation. All the selected boars were in a good health condition, without evident developmental anomalies and showing normal libido. Semen was collected manually in a collection room once per $7 \pm 0.5$ days in all the categories (King and Macpherson, 1973).

For evaluation of sperm morphology, smears of native semen were prepared once per month. The dried smears were dyed according to the methodology of Čeřovský (1976) in a saturated aqueous solution of Congo red followed by $0.5 \%$ aqueous solution of Crystal violet. The morphology of the spermatozoa was assessed using light microscope with oil immersion objective with magnification of x1500.

The results of morphological evaluation were recorded using the DeSMA software. For each spermiogram, 500 sperm cells were evaluated, from which a percent proportion of spermatozoa with pathological defects was counted. The defects of sperm cells were categorized according to their impact on male fertility into "major defects" and "minor defects" (Blom, 1972). Specific morphological defects of both categories are listed in Tab. I.

The recorded data were processed and statistically evaluated using STATISTICA CZ software, version 12.0. Statistical significance of the differences among the groups was determined using the Tukey's test.

\section{RESULTS}

Frequencies of major and minor defects and overall frequencies of abnormalities in ejaculates of boars according to breeds are shown in Tab. II. In this respect, the semen of Czech Landrace boars was characterized by the highest quality as it contained only $5.20 \%$ of sperm cells with major defects, $6.42 \%$ of sperm cells with minor defects and the lowest overall frequency of abnormalities when compared to the other breeds. On the contrary, the least quality semen was obtained from the boars of Duroc, their overall frequency of defective spermatozoa exceeded $20 \%$ with $7.73 \%$ of major and $13.24 \%$ of minor abnormalities.

Numerical and percent structure of ejaculates according to the content of spermatozoa with major defects is presented in Tab. III. Only 85 semen samples out of the overall 1080 contained less than $1 \%$ of spermatozoa with major defects, 507 samples contained $1-5 \%$ of these defects and 488 samples contained even more than $5 \%$ of such abnormalities. The highest quality semen in terms of major defects occurrence was obtained from the boars of Czech Landrace with more than 250 samples out of 370 (nearly $72 \%$ ) characterized by less than $5 \%$ of major defects. On the contrary, more than a half of ejaculates contained at least 5\% of spermatozoa with major defects in the Duroc and Czech Large White boars.

Frequencies of spermatozoa with minor defects are shown in Tab. 4. These abnormalities were more frequent than the major defects in all the breeds. Less than $5 \%$ of spermatozoa with minor defects were present in 383 samples out of the total of 1080. The most samples contained between 5 and $15 \%$ of minor abnormalities and more than $15 \%$ of these defects were found in nearly a quarter of the samples. Same as for the major defects, the lowest frequency of minor defects was observed in the Czech Landrace breed. More than a half of

I: Major and minor defects of spermatozoa

pyriform head, amorphous head, round head, pin head, malformed basis, double head, diadem defect, persistent akroblast, condensed acrosome, swollen acrosome, detached

Major defects acrosome, no acrosome, free heads, proximal cytoplasmic droplet, midpiece defects, primary coiled tail (dag defect), agenesis of tail, double tail

Minor defects macrocephaly, microcephaly, abnormal tail insertion, bent tail, folded tail, broken tail, distal cytoplasmic droplet

II: Frequencies of major and minor defects and overall frequencies of abnormalities in ejaculates of boars

\begin{tabular}{lccc}
\hline \multirow{2}{*}{ Breed } & Major defects & Minor defects & Total \\
\cline { 2 - 4 } & & mean \pm SE & $20.96 \pm 0.21^{\mathrm{c}}$ \\
\hline Duroc & $7.73 \pm 0.14^{\mathrm{b}}$ & $13.24 \pm 0.18^{\mathrm{b}}$ & $17.70 \pm 0.36^{\mathrm{b}}$ \\
Czech Large White & $5.91 \pm 0.29^{\mathrm{a}}$ & $11.79 \pm 0.31^{\mathrm{b}}$ & $11.62 \pm 0.34^{\mathrm{a}}$ \\
Czech Landrace & $5.20 \pm 0.27^{\mathrm{a}}$ & $6.42 \pm 0.28^{\mathrm{a}}$ & $10.01)$ \\
\hline
\end{tabular}

a, b, c - values with different superscripts within a column are highly significantly different $(p<0.01)$ 
the samples obtained from this breed contained less than $5 \%$ of sperm cells with minor defects, while in the other breeds, only less than 26\% (Czech Large White) or 30\% (Duroc) of ejaculates were characterized by such frequency of minor defects.

\section{DISCUSSION}

High content of morphological abnormalities leads to decline of farrowing rate or litter size in pigs (Krajňák, 1995; De Vos et al., 2003, Feitsma et al., 2005), therefore, monitoring of sperm cells with morphological defects is important. Corcuera et al. (2002) presumed that the effect of problematic semen quality on fertility damage of the inseminated sows could reach $33 \%$. It can be deduced from it that the quality level (fertility) of the spermatozoa is a significant marker in the artificial insemination of sows. Differences in the occurrence of specific sperm defects among breeds were also described by Wysokinska et al. (2016). Even boars of the same breed and age can differ in the frequency of spermatozoa with morphological anomalies, which is confirmed also by Pinart et al. (1998) and Kondracki and Wysokinska (2005). Regarding the fact that spermatogenesis in boars lasts nearly 45 days, which are followed by approximately 10-12 days of maturation, most of the abnormalities in spermatozoa arise during this period (Vogler et al., 1991). In this respect, the morphology of spermatozoa reflects the health of seminal tubules and to a lesser extent also of epididymis.

III: Structure of ejaculates as regards the content of spermatozoa with major defects

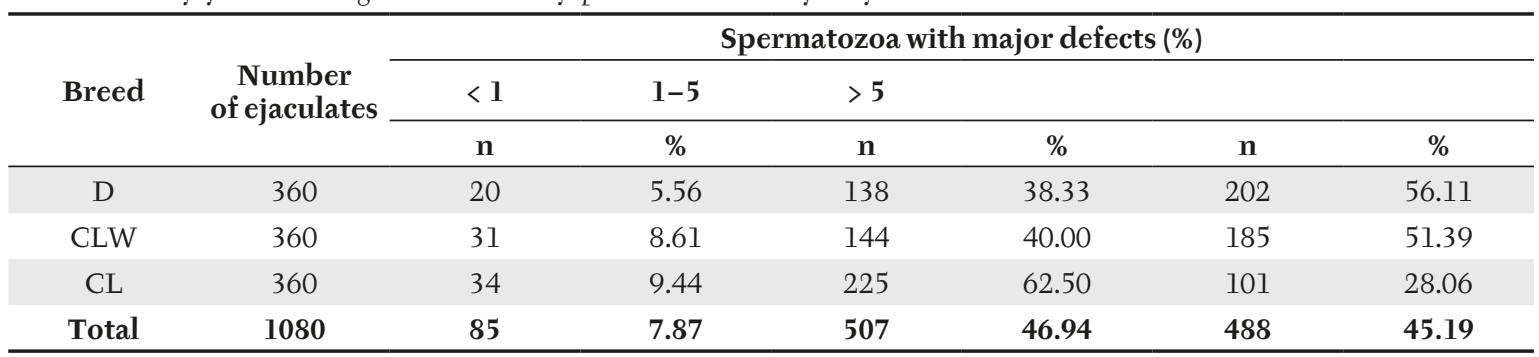

D - Duroc, CLW - Czech Large White, CL - Czech Landrace

IV: Structure of ejaculates as regards the content of spermatozoa with minor defects

\begin{tabular}{|c|c|c|c|c|c|c|c|}
\hline \multirow{3}{*}{ Breed } & \multirow{3}{*}{$\begin{array}{c}\text { Number } \\
\text { of ejaculates }\end{array}$} & \multicolumn{6}{|c|}{ Spermatozoa with minor defects (\%) } \\
\hline & & $<5$ & $5-15$ & $>15$ & & & \\
\hline & & $\mathbf{n}$ & $\%$ & $\mathbf{n}$ & $\%$ & $\mathbf{n}$ & $\%$ \\
\hline CLW & 360 & 93 & 25.83 & 175 & 48.61 & 92 & 25.56 \\
\hline CL & 360 & 182 & 50.56 & 135 & 37.50 & 43 & 11.94 \\
\hline
\end{tabular}

D - Duroc, CLW - Czech Large White, CL - Czech Landrace

\section{CONCLUSION}

The results of the morphological evaluation presented in this study indicate, that frequency of pathological sperm cells depends on the breed. The study also documented differences in character of the defects with variable severity. A thorough detection of morphological anomalies and eradication of their causes are therefore necessary prerequisites for gaining quality semen with high fertilizing capacity. Based on the results of this study, it can be stated that the susceptibility of males to particular types of morphological defects of sperm cells is influenced by the breed.

Acknowledgments

This study was supported by the project of MENDELU internal grant agency, Faculty of AgriSciences No. TP 7/2017.

\section{REFERENCES}

BLOM, E. 1972. The ultrastructure of some characteristic sperm defects and a proposal for a new classification of the bull spermiogram. In: Atti del VII Simposio Int di Zootechnia Milan, pp. 125-139.

COLENBRANDER, B. and KEMP, B. 1990. Factors influencing semen quality in pigs. J. Reprod. Fertil. Suppl., 40: 105-115. 
CORCUERA, B., DE ALBA, C., HERNÁNDEZ - GIL, R. and SAGÜÉS, A. 2002. Identifying abnormalities in boar semen. Pig Progress, 18: 24-27.

ČEŘOVSKÝ, J. 1976. Metoda barvení kančích spermií pro morfologické hodnocení. Živ. Výr., 21: 361-366.

DE VOS, A., VAN DE VELDE, H., JORIS, H., VERHEYEN, G., DEVROEY, P. and VAN STEIRTEGHEM, A. 2003. Influence of individual sperm morfology on fertilization, embryo morfology, and pregnancy outcome of intracytoplasmic sperm injection. Fertil. Steril., 79(1): 42-48.

VÚVEL. 2015. DeSMA (Detailed Sperm Morphology Analysis). Software. Brno: Výzkumný ústav veterinárního lékařství, v. v.i.

FEITSMA, H., BERGSMA, R. and LAAR, A. 2005. Effect of morphological abnormal sperm cells on farrowing rate and litter size in pigs In: Proceedings 7th International Conference on Pig Reproduction. Abstracts of pousters, 12-15 June, Rolduc, The Netherlands.

GAMČÍK, P., KOZUMPLÍK, J., MESÁROŠ, P., SCHVARC, F., VLČEK, Z. and ZIBRÍN, M. 1992. Andrológia a umelá inseminácia hospodárskych zvierat. Bratislava: Nakladatelstvo Príroda.

JELÍNEK, P. and KOUDELA, K. 2003. Fyziologie hospodářských zvírat. Brno: Mendelova zemědělská a lesnická univerzita.

KING, G. J. and MACPHERSON, J. W. 1973. A comparison of two methods for boar semen collection. J. Anim. Sci., 36(3): 563-565.

KLUPCZYNSKI, J., MICINSKI, J. and NOGALSKI, Z. 2000. Effect of age and evaluation season on quality of semen of the Limousine breed bull. Zeszyty Naukowe AR we Wroclawiu. Konferencje XXIV, 375: 237-245.

KONDRAZCKI, S. and WYSOKINSKA, A. 2005. Charakterystyka zmian w budowie morfologicznej plemenikow knura, z uwzglednieniem wieku i rasy rozplodnika. Folia Univ. Agric. Stetin. Zootech., 243: 97-104.

KRAJŇÁK, P. 1995 Vplyv morfologicky abnormálních spermi ́́ kancov na prasnost'inse-minovaných prasníc. Živ. Výr., 40: 537-540.

PINART, E., CAMPS, E., BRIZ, M. O., BONET, S. and EGOZCUE, J. 1998. Unilateral spontaneosus abdominal cryptochidism: structural and ultrastructural study of sperm morfology. Anim. Reprod. Sci, 49: 247-268.

STATSOFT. 2013. Statistica CZ, version 12.0. Tulsa, Oklahoma, USA: StatSoft, Inc.

THUNDATHIL, J., PALASZ, A. T., BARTH, A. D. and MAPLETOFT, R. J. 2001. The use of in vitro fertilization techniques to investigate the fertilizing ability of bovine sperm with proximal cytoplasmic droplets. Anim. Reprod. Sci., 65: 181-192.

VĚŽNÍK, Z., ŠVECOVÁ, D. ZAJÍCOVÁ, A., RUBEŠ, J., RYBÁŘ, R., MACHATKOVÁ, M., and HORÁKOVÁ, J. 2004. Repetitorium spermatologie a andrologie a metodiky spermatoanalýzy. Výzkumný ústav veterinárního lékařství.

VOGLER, C. J., SAACKE, R. G., BAME, J. M., DEJARNETTE, J. M. and MCGILLIARD, M. I. 1991. Effects of scrotal insulation on viability characteristics of cryopreserved bovine semen. J. Dairy Sci., 74(11): 3827-3835.

WYSOKINSKA, A., KONDRACKI, S., BANASZEWKA, D. and KONDRACKA, D. 2016. Frequency of morphological changes in spermatozoa from the boar semen of different breeds. Anim. Sci. Pap. Rep., 24(Suppl. 3): 327-334. 